\title{
Leptin regulation of lipid homeostasis: dietary and metabolic implications
}

\author{
Karen L. Houseknecht ${ }^{1 *}$ and Michael E. Spurlock ${ }^{2}$ \\ ${ }^{1}$ Department of Cardiovascular and Metabolic Diseases, Pfizer Global Research and Development, MS 8220-3071, Eastern \\ Point Road, Groton, CT 06340, USA \\ ${ }^{2}$ Department of Animal Sciences, Purdue University, West Lafayette, IN, USA
}

\begin{abstract}
Leptin is a $16 \mathrm{kDa}$ protein synthesized and secreted primarily from adipocytes. Leptin acts centrally to regulate appetite and energy expenditure and has peripheral effects to coordinate wholebody energy metabolism. Leptin acts as an energy balance and nutrient sensor; its expression and function are regulated by endocrine and dietary factors. Leptin regulates lipid metabolism, specifically lipid storage in adipocytes as well as in skeletal muscle, liver and the pancreas. Effects of leptin on tissue lipid metabolism include regulation of lipogenesis and fatty acid oxidation. Leptin resistance is a hallmark of rodent and human obesity and appears to be due to defects in leptin-receptor signalling (proximal and perhaps distal) as well as impaired leptin transport into the brain. Dietary composition, especially dietary fatty acid intake and profile, impacts on the expression of genes encoding leptin and leptin receptors as well as downstream leptin effectors. Dietary fat consumption, especially consumption of saturated fatty acids, can induce leptin resistance. Leptin has been implicated in nutritional programming during fetal and neonatal growth with long-term effects on susceptibility to obesity, diabetes and CHD in adults.
\end{abstract}

Leptin: Lipid homeostasis: Energy metabolism: Obesity: Nutritional programming

\section{Introduction}

Global rates of adult and childhood obesity have reached epidemic proportions (for a review, see Kopelman, 2000). Given the associated risk for diabetes and cardiovascular disease in obese patients, considerable effort has been spent in understanding candidate genes and pathways involved in the regulation and dysregulation of whole-body energy homeostasis and adiposity. The discovery of leptin, the product of the ob gene, in 1994 (Zhang et al. 1994) changed the field of obesity and metabolic disease research as it provided the first adipocyte-derived endocrine signal linking body fat stores to central feeding and metabolic control centres. A large and growing body of literature details the expression of leptin in lean and obese animals and man and is delineating the integrative role that this energy and nutrient sensor plays in the regulation of wholebody energy homeostasis (for reviews, see Houseknecht \& Portocarrero, 1998; Ahima \& Flier, 2000). In fact, leptin has been shown to play a pivotal role not only in the regulation of body-weight maintenance but is also implicated in immune function, reproduction, bone growth and develop- ment, haematopoiesis, etc. (for reviews, see Fantuzzi \& Faggioni, 2000; Barb et al. 2001; Faggioni et al. 2001; Moschos et al. 2002; Thomas \& Burguera, 2002). It is beyond the scope of the present review to cover the myriad roles of leptin in regulation of these diverse physiological functions. The present review highlights the role of leptin as energy and nutrient sensor, its role in the regulation of lipid homeostasis as well as the impact of nutrition in the regulation of leptin biology.

Leptin was originally cast as an obesity hormone at the time of its discovery due to the profound phenotype observed in mice that lack functional leptin (ob/ob mice; Zhang et al. 1994). Accordingly, leptin biology has been at the centre of intense research effort by the obesity research community. Clearly, mutations in the leptin and leptinreceptor genes are associated with morbid obesity and related pathologies in multiple rodent models (for reviews, see Houseknecht \& Portocarrero, 1998; Ahima \& Flier, 2000). However, in the case of man, with the exception of a few individuals (for a review, see Barsh et al. 2000), mutations in the leptin or leptin-receptor genes are not responsible for obesity. In contrast, mutations of pivotal genes in

\footnotetext{
Abbreviations: AGRP, agouti-related protein; ERK, extracellular signal regulated kinase; MCR, melanocortin receptor; NEFA, non-esterified fatty acid; NPY, neuropeptide Y; POMC, pro-opiomelanocortin; PPAR, peroxisome proliferator activated receptor; SHP-2, SH2-domain containing protein tyrosine phosphatase; SOCS, suppressors of cytokine signalling; SREBP, sterol regulatory element-binding protein; STAT, signal transducers and activators of transcription; ZDF rat, Zucker diabetic fatty rat.

* Corresponding author: Dr Karen L. Houseknecht, fax +1 860715 8557, email Karen_L_Houseknecht@groton.pfizer.com
} 
pathways downstream of leptin such as the melanocortin receptor (MCR)-4 gene have been implicated in human obese populations (Barsh et al. 2000; Farooqi et al. 2000).

\section{Leptin receptor and signalling}

Leptin is synthesized as an $18 \mathrm{kDa}$ protein with a signal sequence that is cleaved to yield the mature $16 \mathrm{kDa}$ hormone. Leptin circulates bound to proteins in serum and is a four-helix bundle cytokine (for reviews, see Houseknecht \& Portocarrero, 1998; Ahima \& Flier, 2000). The leptin receptor (Tartaglia et al. 1995) is a member of the class 1 cytokine receptor family (Tartaglia, 1997; Houseknecht \& Portocarrero, 1998; Sweeney, 2002). Leptin-receptor isoforms (Ob-Ra, Ob-Rb, Ob-Rc, Ob-Rd, Ob-Re, Ob-Rf) arise from alternative splicing and represent variants that differ at the carboxy terminus, all resulting in truncated intracellular domains except for the 'long-form' leptin receptor, $\mathrm{Ob}-\mathrm{Rb}$. The $\mathrm{Ob}-\mathrm{Rb}$ isoform is highly expressed in feeding centres in the hypothalamus and is believed to mediate the effects of leptin on feeding behaviour and metabolic rate.

The various short forms of the leptin receptor are widely expressed in many tissues, yet the physiological role(s) of these receptors remain to be fully elucidated. A soluble leptin receptor $(\mathrm{Ob}-\mathrm{Re})$ that lacks both the trans-membrane and intracellular domains is one of the plasma proteins that bind leptin in circulation (Tartaglia et al. 1995; Houseknecht et al. 1996; Sinha et al. 1996; Friedman \& Halaas, 1998). Ob-Re binds leptin at a 1:1 ratio and has been hypothesized to modulate leptin activity. The expression of Ob-Re changes in various physiological and pathophysiological states in animals and man including weight loss and in eating disorders such as anorexia nervosa and bulimia nervosa (Laimer et al. 2002; Monteleone et al. 2002; Ogier et al. 2002) but the physiological implications of the soluble receptor are currently unknown.

Fig. 1 illustrates our current understanding of the basic signalling pathways emanating from leptin receptors.

Leptin binding to its receptors results in receptor dimerization, an apparent prerequisite for signalling (White et al. 1997). Receptor homodimerization of Ob-Rb (long-form receptor) signals activation of the janus-activated kinases-STAT pathway, consistent with other members of this class of cytokine receptors (for a comprehensive review, see Sweeney, 2002).

In addition to STAT activation, leptin receptors appear to signal via additional pathways. Leptin receptors can activate insulin receptor substrate phosphorylation, phosphatidylinositol 3-kinase activation, as well as activation of extracellular signal regulated kinase (ERK) (or mitogenactivated protein kinase) pathways (for a review, see Sweeney, 2002). Tyrosine-985 appears to be necessary for maximal leptin-induced activation of the ERK pathway (Banks et al. 2000). SHP-2 is a positive effector of ERK activation mediated by both long- and short-form leptin receptors (Bjorbaek et al. 2001). SHP-2 binds to tyrosine985 on $\mathrm{Ob}-\mathrm{Rb}$ and impacts ERK activation by two distinct pathways (Bjorbaek et al. 2001).

Signalling via leptin receptors is subject to negative regulation. One method of negative feedback is via SOCS (Krebs \& Hilton, 2000; Nicola \& Greenhalgh, 2000),

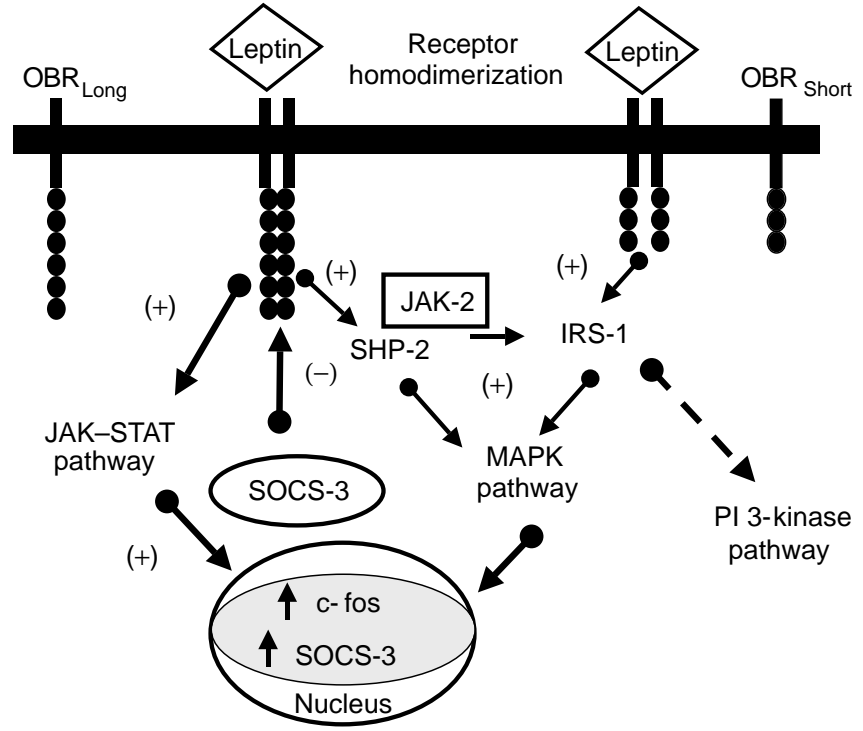

Fig. 1. Signalling pathways emanating from leptin receptors. OBR, leptin receptor; JAK, janus-activated kinases; SHP-2, SH2-domain containing protein tyrosine phosphatase; IRS, insulin receptor substrate; STAT, signal transducers and activators of transcription; SOCS-3, suppressors of cytokine signalling-3; MAPK, mitogenactivated protein kinase; PI, phosphatidylinositol; $(+)$, stimulate; $(-)$, inhibit.

specifically SOCS-3 (Bjorbaek et al. 1999, 2000). The Ob$\mathrm{R}$ tyrosine-985 residue plays a pivotal role not only in leptin-receptor activation, but is also pivotal in the feedback inhibition of the leptin receptor by SOCS-3 as it specifically binds to Ob-R tyrosine-985 (Bjorbaek et al. 2000). Attenuation of leptin signalling via leptin-induced SOCS-3 expression in hypothalamic neurons is at least one mechanism underlying leptin resistance, as discussed on p. 87.

\section{Leptin-receptor signalling in the hypothalamus}

Leptin receptors $(\mathrm{Ob}-\mathrm{Rb})$ are expressed in neurons of the arcuate nucleus of the hypothalamus, neurons pivotal to the regulation of appetite, energy expenditure and ultimately body weight (for detailed reviews, see Ahima et al. 2000; Schwartz, 2001). Both appetite-stimulating (orexigenic) and appetite-inhibiting (anorexigenic) neurons express $\mathrm{Ob}$ $\mathrm{Rb}$. Activation of leptin signalling in the orexigenic neurons culminates in down regulation of the expression of the neurotransmitters neuropeptide Y (NPY) and agouti-related protein (AGRP). Activation of the NPY pathway profoundly stimulates appetite and lowers energy expenditure resulting in obesity. Leptin-induced down regulation of NPY expression is at least one mechanism by which leptin regulates appetite and energy expenditure (Ahima et al. 2000).

AGRP is the naturally occurring antagonist of MCR; antagonism of MCR-4 by AGRP results in hyperphagia and attenuation of leptin-induced anorexia (Fan et al. 1997). Conversely, agonism of MCR by the endogenous agonist, $\alpha$-melanocyte stimulating hormone, culminates in the inhibition of feeding and stimulation of thermogenesis. 
Activation of leptin signalling pathways results in an increase in expression of pro-opiomelanocortin (POMC), the precursor of $\alpha-\mathrm{MSH}$, as well as the anorexigenic peptide cocaine- and amphetamine-related transcript (Schwartz et al. 1997; Elias et al. 1999; Elmquist et al. 1999). As leptin regulates the expression of both the endogenous agonist and antagonist of MCR-4, a hypothalamic receptor pivotal in regulation of body weight in rodents (Huszar et al. 1997) and a significant site of mutations found in obese human populations (4-5\% of morbid obesity in the population; Farooqi et al. 2000), it appears that this is a major downstream effector pathway for leptin regulation of appetite and energy homeostasis.

\section{Leptin: energy-balance sensor}

The ability of exogenous leptin to regulate appetite and energy expenditure in rodents with subsequent loss of adipose tissue but not lean body mass has led to the notion that leptin is an anti-obesity hormone (for reviews, see Friedman \& Halaas, 1998; Houseknecht \& Portocarrero, 1998). The observation that obesity can occur despite high circulating leptin concentrations in rodents and man has led to the notion of leptin resistance (discussed in detail on p. 87). It has been proposed that obesity in the face of leptin resistance reflects the evolutionary advantage of being able to store excess energy as lipid during times of nutritional plenty (Flier, 1998). This has led to the notion that leptin's primary physiological role is in sensing negative energy balance and coordinating physiological signals leading to whole-body adaptation to fasting (Flier, 1998; Ahima \& Flier, 2000).

Studies from several groups (Ahima et al. 1996; Legradi et al. 1997; Yu et al. 1997; Finn et al. 1998; Lord et al. 1998; Nagatani et al. 1998) have shown that, indeed, prevention of the fasting-induced fall in leptin concentrations by the administration of exogenous leptin treatment during fasting is able to at least partially overcome the metabolic, endocrine, reproductive and immune system adaptations to starvation.

\section{Leptin as a nutrient sensor}

Intense study is underway to determine the mechanism(s) by which leptin 'senses' energy balance. Linked to energy sensing is the notion that leptin serves as a nutrient sensor, specifically sensing nutrient flux in adipocytes and other cells. One way this could be accomplished is via changes in circulating insulin concentrations. Insulin levels in blood change rapidly in response to feeding and insulin has been shown to regulate leptin gene expression in many species (for reviews, see Houseknecht \& Portocarrero, 1998; Ahima \& Flier, 2000).

The regulation of leptin expression by changes in nutrient flux appears to involve more than changes in insulin concentrations, however. Work from several laboratories has implicated the hexosamine biosynthetic pathway in leptin's role as cellular nutrient sensor.

Marshall et al. (1991) proposed that cellular hexosamine biosynthesis is an important mechanism by which cellular glucose flux in cells is sensed. Uridine-diphospho- $N$-acetylglucosamine, the endproduct of hexosamine biosynthesis, is used in $o$-linked glycosylation reactions; important regulatory steps in gene transcription. Specifically, the activity of some transcription factors is modified by $o$-linked glycosylation. Leptin expression in the adipose tissue of man (Considine et al. 2000) and rodents (Wang et al. 1998, 1999b; McClain et al. 2000; Obici et al. 2002b) is regulated by the hexosamine biosynthetic pathway, consistent with the observation that leptin expression in adipocytes in vitro is more sensitive to glucose concentrations than insulin (Mueller et al. 1998). It appears that the mechanisms by which hexosamine biosynthesis regulates leptin production involve the regulation of activity of transcription factors. In experiments using 3T3-L1 adipocytes transfected with a leptin gene promoter-luciferase reporter construct, Zhang et al. (2002) found that leptin production in 3T3-L1 adipocytes is stimulated by the metabolism of glucose to hexosamines via transcriptional mechanisms in the proximal promoter of the leptin gene.

In addition to its effects on leptin gene expression, recent work by Obici et al. (2002b) reveals that the hexosamine pathway is also involved in regulating the expression of a cluster of mitochondrial genes involved in oxidative phosphorylation in skeletal muscle and linked to whole-body energy expenditure. Short-term overfeeding experiments in rodents replicated this transcriptional pattern suggesting that this adaptation to nutrient abundance occurs under physiological conditions. These data reinforce the notion that the hexosamine biosynthetic pathway plays a major role in cellular nutrient sensing, and in the regulation of whole-body energy balance due to its modulation of leptin expression and insulin action in adipose tissue and skeletal muscle (Wang et al. 1998, 1999b; McClain et al. 2000).

\section{Nutritional regulation of leptin biology}

As leptin has been implicated as a major sensor of energy and nutrient balance it is not surprising that the leptin axis is regulated by nutritional status. The vast majority of published manuscripts examining the impact of nutrition on leptin expression and activity have focused on energy intake, namely comparison of ad libitum feeding of highly palatable, and often high-fat, diets $v$. low-fat diets. Additionally, a large body of literature has compared effects of ad libitum feeding with food deprivation (acute or chronic fasting) on leptin expression. Data in species spanning from rodents to livestock to man have shown that chronic over-consumption of energy leads to increased leptin gene expression coincident with increasing adiposity (for reviews, see Houseknecht \& Portocarrero, 1998; Ahima \& Flier, 2000; Barb et al. 2001). Likewise, many laboratories have shown that fasting results in significant down regulation of leptin expression in many species. Indeed, food deprivation has a more profound and immediate impact on leptin expression compared with chronic overfeeding. Although relatively few in number, studies examining the role of specific nutrients on leptin gene expression and activity are beginning to appear in the published literature. Those studies will be the focus of the present review. 


\section{Effect of dietary fatty acids on the regulation of appetite and leptin biology}

A large body of literature documents that consumption of diets high in fat affects feeding behaviour and the expression of many genes involved in energy homeostasis. As nutrient intake and composition regulate circulating insulin and leptin concentrations, it has been generally accepted that these hormones modulate the effects of nutrients on feeding behaviour and energy homeostasis. A recent report, however, indicates that fatty acids, per se, can act at the site of hypothalamic feeding centres to regulate feeding and insulin action (Obici et al. 2002a).

Obici et al. (2002a) reported that a single bolus injection of the long-chain fatty acid, oleic acid, into the third cerebral ventricle resulted in a reduction of food intake by 24 and $48 \mathrm{~h}$ post-dose in Sprague-Dawley rats. This change in feeding behaviour was independent of plasma leptin concentrations and was associated with a reduction in hypothalamic NPY mRNA abundance. These data indicate that this fatty acid serves as a direct signal of nutrient abundance within hypothalamic feeding and metabolic centres. In addition to feeding, intracerebroventricular oleic acid treatment also markedly and rapidly inhibited hepatic glucose production with associated lowering of plasma glucose and insulin. Furthermore, these effects required activation of central nervous system $\mathrm{K}_{\mathrm{ATP}}$ channels (Obici et al. 2002a). These data provide additional evidence that fatty acids can serve as a direct signal of nutrient abundance to the central nervous system, and these effects share common central mechanistic pathways with hormones such as leptin and insulin that regulate whole-body energy homeostasis.

Many groups have examined the effect of high fat feeding on leptin expression; consumption of high-fat diets leads to increased leptin gene expression in adipose tissue (for reviews, see Caro et al. 1996; Houseknecht \& Portocarrero, 1998). Many studies are confounded by differences in energy intake among treatment groups, and the role of specific fatty acids on leptin biology is not widely documented.

Raclot et al. (1997) provided the first evidence that fatty acid profile, specifically consumption of $n-3$ polyunsaturated fatty acids, resulted in the down regulation of rat adipocyte genes involved in lipid metabolism, adipogenesis and feeding, including leptin. In contrast, Cha \& Jones (1998) reported that rats fed diets high in $n-3$ polyunsaturated acids (fish oil or safflower-seed oil) developed hyperleptinaemia despite reduced perirenal fat mass and adipocyte size compared with animals fed beef tallow-supplemented diets. These authors did not quantify leptin expression in adipose tissue, however, so it is not clear if their results are in conflict with those reported by Raclot et al. (1997). Recently, Peyron-Caso et al. (2002) examined the effect of consumption of fish oil on leptin expression in rats made insulin resistant by consumption of high-sucrose diets. They found that consumption of fish oil increased plasma leptin concentrations compared with controls, and prevented the sucrose-induced increase in adiposity and plasma triacylglycerol and non-esterified fatty acid (NEFA) concentrations. These authors (Peyron-Casa et al. 2002) concluded that plasma leptin concentrations could be inappropriately high relative to body fat mass in rats fed diets supplemented with $n-3$ polyunsaturated fatty acids. Finally, Takahashi \& Ide (2000) reported that leptin expression is differentially regulated by dietary fat (safflower-seed oil) in various adipose tissue depots in rats; it is not clear which adipose depots provide the greatest contribution of leptin found in circulation in these nutritional experiments.

Spurlock et al. (2000) examined the effect of specific dietary fat sources (beef tallow, safflower-seed oil and fish oil) on leptin expression in porcine adipose tissue. It was found that leptin gene expression in porcine subcutaneous adipose tissue is unresponsive to consumption of diets supplemented with saturated or polyunsaturated fats. It is important to note that for pigs, unlike many rodent strains, consumption of high-fat diets leads to reduction of food intake due to the increased energy density of the diet compared with diets not supplemented with dietary fat. This may explain the different responses to dietary fat supplementation between species.

Specific isomers of fatty acids may also have differential effects on leptin gene expression. Studies where animals are treated with conjugated linoleic acid, a group of positional isomers of linoleic acid, have revealed that coincident with anti-obesity (Park et al. 1997, 1999; West et al. 1998; Tsuboyama-Kasaoka et al. 2000; Rahman et al. 2001; Ryder et al. 2001) and anti-diabetic effects in rodents (Houseknecht et al. 1998; Ryder et al. 2001) is the observation that plasma and tissue leptin content are, for the most part, down regulated compared with controls (Medina et al. 2000; Tsuboyama-Kasaoka et al. 2000; Yamasaki et al. 2000; Ryder et al. 2001). The mechanism(s) underlying the conjugated linoleic acid effects remain to be elucidated but could be linked to peroxisome proliferator activated receptor (PPAR) activation and/or changes in food intake and metabolic rate. Additionally, Kang \& Pariza (2001) have shown that leptin secretion from 3T3-L1 adipocytes treated with the trans-10, cis-12 isomer of conjugated linoleic acid was reduced compared with control, implicating effects on both gene expression and perhaps protein secretion.

In addition to regulating the expression of leptin, consumption of diets high in fat also regulates the expression of leptin receptors and neuropeptides downstream of leptin signalling including POMC and NPY. Expression of leptinreceptor mRNA in the arcuate nucleus and choroid plexus was increased in obese mice fed high-fat diets ( 8 weeks) compared with those fed low-fat diets (Lin et al. 2000). The increase in leptin-receptor expression was coincident with a significant down regulation in the abundance of NPY mRNA. However, following 19 weeks on the high-fat diet, leptin-receptor expression was down regulated. Consistent with the notion that leptin-receptor expression is regulated by high fat feeding, Boado et al. (1998) reported that the short isoform of the leptin receptor, Ob- $\mathrm{Ra}$, was up regulated in microvessels of the blood-brain barrier in rats fed high-fat diets. Finally, as dietary fats are able to alter the phospholipid composition of brain membranes (Gibson et al. 1984), which in turn can alter receptor function, it is possible that consumption of diets high in saturated or unsaturated fatty acids could have effects on leptin-receptor function. 
In addition to leptin receptors, high fat feeding regulates expression of neurotransmitters downstream of leptin such as NPY, AGRP and POMC (Giraudo et al. 1994; Guan et al. 1998; Lin et al. 2000; Wang et al. 2002). Furthermore, specific fatty acids differentially affect neurotransmitter expression in mice, as the consumption (for 1 or 7 weeks) of diets high in saturated fat down regulated NPY and AGRP expression compared with diets high in polyunsaturated fats or a low-fat diet (Wang et al. 2002).

Consumption of fatty acids not only regulates expression of neurotransmitters involved in feeding, but also has an impact on hypothalamic neuronal activity. Wang et al. (1999a) examined the effect of dietary fat intake on the function of hypothalamic neurons, using c-fos-like immunoreactivity as a biomarker. They reported that consumption of diets high in saturated fat resulted in an increase in lateral, and decrease in ventromedial, hypothalamic neuronal activity, predictive of, and associated with, hyperphagia, lower metabolic rate and body-weight gain. These authors also found that in contrast, consumption of diets high in polyunsaturated fatty acids did not alter hypothalamic neuronal function, when compared with animals fed a low-fat diet. Taken together, these data support the notion that dietary fat composition and quantity can profoundly regulate leptin biology as well as hypothalamic signalling pathways downstream of the leptin receptor.

\section{Leptin resistance: receptor signalling attenuation and leptin transport attenuation}

The notion of 'leptin resistance' originated with the observations of many investigators that in most obese mammals, including man, circulating leptin concentrations are high, indicating that the organism is resistant to the effects of leptin to inhibit feeding and increase metabolic rate. Leptin resistance is associated with diet-induced obesity (Campfield et al. 1995; Van Heek et al. 1997; Widdowson et al. 1997; El-Haschimi et al. 2000; Lin et al. 2001b), acute overfeeding (Wang et al. 2001a) and ageing (Ahren et al. 1997; Li et al. 1997; Qian et al. 1998a; SanchezRodriguez et al. 2000; Scarpace \& Tumer, 2001; Wang et al. 2001b; Gabriely et al. 2002). Also, various dietary and physiological and pathophysiological states as well as exogenous leptin administration can differentially induce central or peripheral leptin resistance (Van Heek et al. 1997; Lin et al. 2001b; Scarpace et al. 2002a). The mechanism(s) responsible for leptin resistance are under intense investigation; current concepts are illustrated in Fig. 2.

At least one mechanism underlying the phenotype of leptin resistance is the apparent saturation of the blood-brain barrier transport system in obese individuals. Leptin crosses the blood-brain barrier via a saturable system (Banks et al. 1996; Bartolome \& Couce, 2001). The precise mechanisms are not fully elucidated, but the expression of short-form leptin receptors (Bjorbaek et al. 1998; Hileman et al. 2002) in brain microvessels comprising the blood-brain barrier is consistent with the notion that leptinreceptor isoforms are involved in this transport system (for a review, see Burguera \& Couce, 2001).

The notion that impaired leptin transport into the brain underlies leptin resistance is supported by the findings that

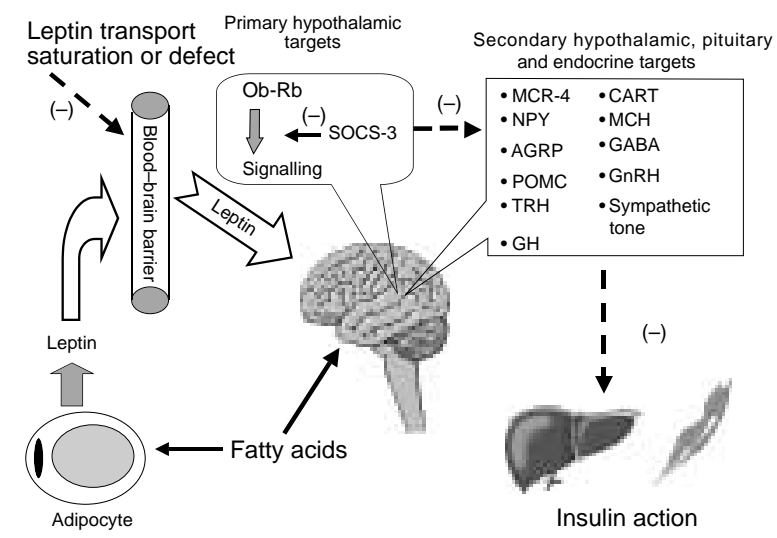

Fig. 2. Current concepts of leptin resistance Ob-Rb, long-form leptin receptor; SOCS-3, suppressors of cyotokine signalling-3; MCR-4, melanocortin receptor-4; NPY, neuropeptide Y; AGRP, agouti-related protein; POMC, pro-opiomelanocortin; $\mathrm{TRH}$, thyrotropin-releasing hormone; $\mathrm{GH}$, growth hormone; CART, cocaine and amphetamine-related transcript; $\mathrm{MCH}$, melanin concentrating hormone; GABA, $\gamma$ amino butyric acid; $\mathrm{GnRH}$, gonadotropin-releasing hormone; $(-)$, lesions involved in leptin resistance mechanism(s).

centrally administered leptin was more efficacious than peripherally administered leptin in stimulating hypophagia and hypothalamic signalling events (Van Heek et al. 1997; El-Haschimi et al. 2000). Hileman et al. (2002) recently reported that leptin uptake into the brain is reduced in mice lacking leptin receptors or rendered obese due to dietary manipulation. Additionally, they reported that New Zealand obese mice have reduced leptin uptake into the brain yet respond to exogenous leptin administered via an intracerebroventricular cannula, again consistent with the hypothesis that leptin resistance is due, at least in part, to a defect in leptin transport into the brain.

A second mechanism underlying leptin resistance appears to be attenuation of leptin-receptor signal transduction. The precise mechanisms underlying the attenuation in leptin signalling observed with leptin resistance (El-Haschimi et al. 2000; Scarpace \& Tumer, 2001) are not known; however, SOCS-3 expression and activity may play a role. SOCS-3 expression is induced by leptin-stimulated STAT-3 activation and is up regulated in the hypothalamus of obese animals (Bjorbaek et al. 1998, 1999; Banks et al. 2000) and in cell models of leptin resistance (Sweeney, 2002). In addition to the hypothalamus, SOCS-3 is over-expressed in white adipose tissue of obese rodents and inhibits insulin signalling in adipocytes (Emanuelli et al. 2001).

Recent evidence (Scarpace et al. 2002a,b) indicates dissociation in the effects of leptin resistance on appetite and thermogenesis. Chronic leptin treatment (via adenovirus) induced leptin resistance in terms of appetite regulation, while the thermogenic effect of leptin was sufficient to maintain the weight loss achieved during the period of hypophagia. These authors also reported that STAT-3 phosphorylation was maintained over the course of the study (in the face of elevated SOCS-3), indicating that mechanisms downstream of STAT activation are responsible for the differential leptin resistance. 
The concept of leptin resistance is growing in complexity with the steady emergence of data (predominantly from the rodent literature) indicating that the onset of leptin resistance can be quite rapid (days; well before the development of obesity), and the rate and duration of onset and degree of hyperleptinaemia associated with leptin resistance may differ depending upon the physiological response being studied. Some authors (Arch et al. 1998) have argued that leptin resistance may not be a relevant physiological phenomenon in obese human individuals given the fact that diminished response to leptin (at least in terms of feeding) can occur within the normal range of plasma leptin concentrations. As leptin has many physiological roles in addition to appetite regulation, the notion of leptin resistance is being expanded by many scientists to encompass the complexity of leptin action in multiple physiological and pathophysiological systems. Recent work by Mark et al. (2002) advances the concept of selective leptin resistance in man in the context of physiological effects of leptin on cardiovascular biology. They suggest that obese individuals can be resistant to the appetite-regulating effects of leptin yet remain sensitive to the increased sympathetic activity and arterial pressure induced by hyperleptinaemia. Clearly, additional research is needed to elucidate the mechanisms underlying leptin resistance and to determine the full cohort of physiological implications of hyperleptinaemia associated with obesity and the metabolic syndrome in man.

\section{Leptin resistance: role of nutrition}

The majority of work examining leptin resistance in vivo has examined the effect of diet-induced obesity on leptin action. In fact, the first published evidence of leptin resistance described the phenomenon in mice fed a high-fat diet (diet-induced obesity; Campfield et al. 1995). Specifically, mice made obese by diet required a higher dose of exogenous leptin than ob/ob mice to elicit similar weight loss (30 v. $6 \mu \mathrm{g}$ leptin, respectively). Mooradian et al. (2000) found that consumption of monosaccharide-enriched diets caused hyperleptinaemia with no change in food intake; the hallmark of leptin resistance. With the exception of the work of Mooradian et al. (2000), the majority of the work examining the effect of nutrition on leptin resistance has examined the effect of dietary fat consumption on leptin resistance.

The ability of high fat feeding to induce leptin resistance (lack or attenuated feeding response to intracerebroventricular or peripheral leptin administration) has been observed in rats (Widdowson et al. 1997; Lin et al. 1998, 2001b) as well as mice, and the effect of fat feeding is reversible upon dietary change to a low-fat diet, in the absence of reduced body weight (Widdowson et al. 1997). Furthermore the dietary fat-induced leptin resistance occurs quickly (within $5 \mathrm{~d}$ ), as does the reversal of leptin resistance following the change from a high-fat to a low-fat, high-carbohydrate diet (within 1-5 d; Lin et al. 2001b).

The effect of high fat feeding to induce leptin resistance is complex in that in some rodent models the effect is to induce peripheral but not central leptin resistance (Van Heek et al. 1997; Lin et al. 1998; El-Haschimi et al. 2000). The reasons for differences among rodent strains in terms of presentation of central $v$. peripheral leptin resistance are not clear; however, the data suggest that multiple mechanisms including attenuated signalling and transport into the brain underlie leptin resistance in diet-induced obesity.

\section{Nutritional programming of obesity: leptin as candidate gene}

The concept that nutritional exposure during critical developmental windows pre- and postnatally can influence or 'programme' long-term growth, development and disease susceptibility is known as 'nutritional programming' (for a brief review, see Lucas, 1994). Nutritional programming has been well described in animals and evidence is beginning to mount that it may play a role in human development as well. Given the recent increase in global rates of obesity and the coincident negative impact upon public health, the search for candidate genes that may be involved in the regulation of adiposity and the predisposition to obesity, insulin resistance, hypertension and other sequelae associated with the metabolic syndrome has accelerated. Data suggest that leptin may be a candidate gene involved in regulation of fetal programming for obesity and diabetes.

A historical cohort study of men born during the Dutch famine of 1944-5 revealed elevated rates of obesity in young adult men born of mothers who were exposed to undernutrition during the first half of gestation whereas men whose mothers were exposed to famine during the last trimester and during the early postnatal period had lower rates of adult obesity (Ravelli et al. 1976). Others have reported that low birth weight in human infants is associated with adult insulin resistance, hypertension and CHD (Lucas, 1994; Barker, 1995). Additionally, infants born of mothers with non-insulin-dependent or insulin-dependent diabetes mellitus or glucose intolerance have a higher risk of developing childhood obesity (Silverman et al. 1991).

The mechanism(s) underlying the effects of fetal programming on subsequent obesity remain to be fully elucidated. It has been proposed that undernutrition during a critical period of hypothalamic development plays a critical role in this process (Reynolds \& Phillips, 1998). Additionally, leptin is now implicated in playing a role in fetal programming (Ekert et al. 2000). Infants from diabetic mothers have elevated cord blood leptin concentrations, and these concentrations are positively correlated with infant adiposity (Cetin et al. 2000). Vickers et al. (2000) developed a rodent model of fetal undernutrition to predict effects of prenatal nutritional programming associated with intra-uterine growth retardation in man. These authors reported that offspring from underfed mothers were smaller at birth and had higher food intake early in the postnatal period that was maintained throughout life. Additionally, consumption of a high-energy fat-supplemented diet postnatally exacerbated the hyperphagia in these animals. In addition to adult hyperphagia, offspring from underfed mothers presented hyperinsulinaemia, hyperleptinaemia and elevated systolic blood pressure. These data are consistent with the notion that fetal programming plays a key role in predisposing offspring to obesity and metabolic disease as adults. In a subsequent report, these authors provide evidence that the negative effects of fetal undernutrition on the 
programming of adult metabolic disease could be at least partially overcome by exogenous insulin-like growth factor-1 treatment (Vickers et al. 2001).

Finally, Singhal et al. (2002) examined the effect of nutritional programming during the early postnatal period and found that a high plane of nutrition during this period is positively correlated with the development of adult obesity. Specifically, serum leptin concentrations were quantified in adolescent children who had been born preterm and assigned at birth to receive either banked breast milk, nutrient-enriched preterm formula or normal formula. The leptin:body-fat mass value was greater in children receiving higher-energy preterm formula compared with either standard formula or breast milk despite no significant differences in adiposity. These authors suggest that the leptin:fat mass ratio is an early indicator of leptin resistance and subsequent obesity.

\section{Leptin regulation of lipid metabolism}

In this section, the regulation of lipogenesis and lipolysis in pre-adipocytes and adipocytes by leptin will be discussed. The discovery of the obese gene (Zhang et al. 1994) was followed quickly by the determination that exogenous leptin reduced adiposity in the leptin-deficient obese mouse (Pelleymounter et al. 1995), decreased feed intake (Campfield et al. 1995), and stimulated energy expenditure (Halaas et al. 1995). When Bai et al. (1996) reported that incubating pre-adipocyte cultures with leptin reduced acetyl-CoA carboxylase expression and activity, and decreased lipogenesis, it became apparent that leptin might act directly upon the adipocyte. These findings, coupled with the presence of leptin receptors in adipose tissue and skeletal muscle of several species (Tartaglia et al. 1995; Löllmann et al. 1997; Lin et al. 2000), prompted investigations of the role of leptin in lipid metabolism in the adipocyte. Results of several investigations have established unequivocal linkages of leptin to lipid metabolism in the adipocyte.

In rodent models, leptin acts directly to suppress the inhibition of $\beta$-adrenoceptor-mediated lipolysis by insulin, and simultaneously reduces insulin-induced glucose transport and lipogenesis (Müller et al. 1997), and similar effects have been reported in porcine adipocytes derived from stromal-vascular cultures (Ramsay, 2001). However, leptin also acts directly to stimulate lipolysis in adipocytes in the absence of insulin (Frühbeck et al. 1997, 1998). Mechanistically, several things must be considered. Hormone-sensitive lipase is activated by protein kinase A as a result of the production of cAMP by adenylate cyclase, and is the major mediator of lipolysis within the adipocyte (Ramsay, 1996). Although the effect of leptin on the expression of hormone-sensitive lipase in adipose tissue has been addressed in two rodent studies, one in which expression was increased (Sarmiento et al. 1997), and one in which it was not (Scarpace et al. 1998), the regulation of the adenylate cyclase-cAMP system has not been studied. Leptin expression itself is down regulated by cAMP (Slieker et al. 1996), and in the study of Wang et al. $(1999 c)$, leptin stimulated lipolysis and also decreased leptin expression. If noradrenaline, a potent inducer of cAMP production, had reduced leptin expression, one might conclude that leptin acts solely through the production of cAMP to activate lipolysis. However, this is not the case. Recent work published by Frühbeck et al. (2001) indicates that leptin antagonizes the tonic inhibition of lipolysis by adenosine. Leptin is a member of the class-I family of helical cytokines (Madej et al. 1995), as is growth hormone. It is thus interesting that growth hormone, with similarities to leptin in receptor signalling (Tartaglia et al. 1995), alters the functionality of the inhibitory $G$ protein (i.e. diminished ADP-ribosylation by pertussis toxin) in adipose tissue (Houseknecht \& Bauman, 1997). In this study, the diminished functionality of inhibitory $\mathrm{G}$ protein was associated with an enhancement of lipolysis by growth hormone. Although similar results were not obtained in ovine adipocytes, growth hormone nonetheless antagonized the anti-lipolytic action of an adenosine analogue, an effect probably stemming from a stifled interaction between the inhibitory $\mathrm{G}$ protein $\alpha$ subunit and adenylate cyclase (Doris et al. 1998).

It is also important to consider recent publications in which leptin has been reported to stimulate phosphodiesterase activity (Zhao et al. 1998), the mechanism that underlies the suppression of cAMP-mediated insulin secretion by leptin in pancreatic islets (Ahren \& Havel, 1999). It is perplexing that leptin mimics insulin signalling and antagonizes the stimulation of cAMP production by glucagon in isolated hepatocytes (Zhao et al. 2000). However, the absence of the long form of the leptin receptor in these hepatocytes indicates that this response is mediated by the short receptor isoform. This is consistent with the findings of Müller et al. (1997), in which leptin failed to influence lipolysis in the $d b / d b$ mouse, an obese model that does not express the long form of the leptin receptor, but does express the short form. It is probable that the stimulation of lipolysis and attenuation of lipogenesis in the adipocyte is mediated via the long form of the leptin receptor.

\section{Leptin regulation of fatty acid oxidation}

Here, the fatty acid oxidation, adipose ablation and apoptosis in adipose tissue as caused by leptin will be considered. Early work with models in which hyperleptinaemia was induced (Chen et al. 1996; Shimabukuro et al. 1997) indicated that specific adipose depots were virtually obliterated. Furthermore, the recovery of body fat in hyperleptinaemic rats was much slower than in diet-matched controls (Higa et al. 2000). The implications of these results were that there was a sustained impact of hyperleptinaemia on the ability of adipocytes to accumulate and store lipid. A portion of this response is possibly related to an induction of apoptosis and loss of adipocytes caused by elevated leptin concentrations within the brain (Qian et al. 1998b), if the higher circulating concentrations also achieve higher concentrations within the central nervous system. However, the majority of the response is probably due to an induction of fatty acid release, and concomitant up regulation of genes that regulate fatty acid oxidation (i.e. acyl-CoA oxidase and carnitine palmitoyl transferase) that is driven by increased PPAR $\alpha$ expression (Wang et al. 1999c). In fact, an up regu- 
lation of PPAR $\alpha$ has recently been shown to be a prerequisite for depletion of body fat by leptin. Using wild-type and PPAR $\alpha^{-1-}$ mice, Lee et al. (2002) determined that the depletion of body fat in the null mice during hyperleptinaemia is markedly lower than in wild-type mice. This effect was associated in part with the failure of hyperleptinaemia to achieve an up regulation of carnitine palmitoyl transferase in adipose tissue due to the absence of PPAR $\alpha$.

The physiological changes associated with hyperleptinaemia shift the metabolic goal of adipocytes from lipid storage to lipid disposal (Fig. 3). Leptin binding to the long form of the receptor attenuates lipogenic activity through the suppression of acetyl-CoA carboxylase and fatty acid synthase activity. Lipolysis is stimulated by direct or indirect activation of hormone-sensitive lipase through antagonisms of the inhibitory effects of adenosine and insulin. The expression of PPAR $\alpha$ is increased, and up regulates the expression of oxidative genes, acyl-CoA oxidase, carnitine palmitoyl transferase-1, and uncoupling proteins. Consequently, the cellular oxidation of NEFA is increased and the majority of NEFA are consumed internally. Also of considerable significance is that leptin ultimately results in a de-differentiation of adipocytes (Zhou et al. 1999), as indicated by the loss of adipocyte marker (aP2) and concomitant appearance of the pre-adipocyte marker, Pref-1. Collectively, these findings indicate that leptin may be used to reduce adipose mass, but it is important to note that these extreme results are achieved only with pharmacological circulating concentrations of leptin (Higa et al. 2000) and are not indefinite.

Although the most pronounced effects of leptin on body fat are achieved with pharmacological blood levels, significant shifts in metabolism have been noted under less extreme conditions. Specifically, Chen \& Heiman (2000, 2001) have shown in rodent models that daily peripheral

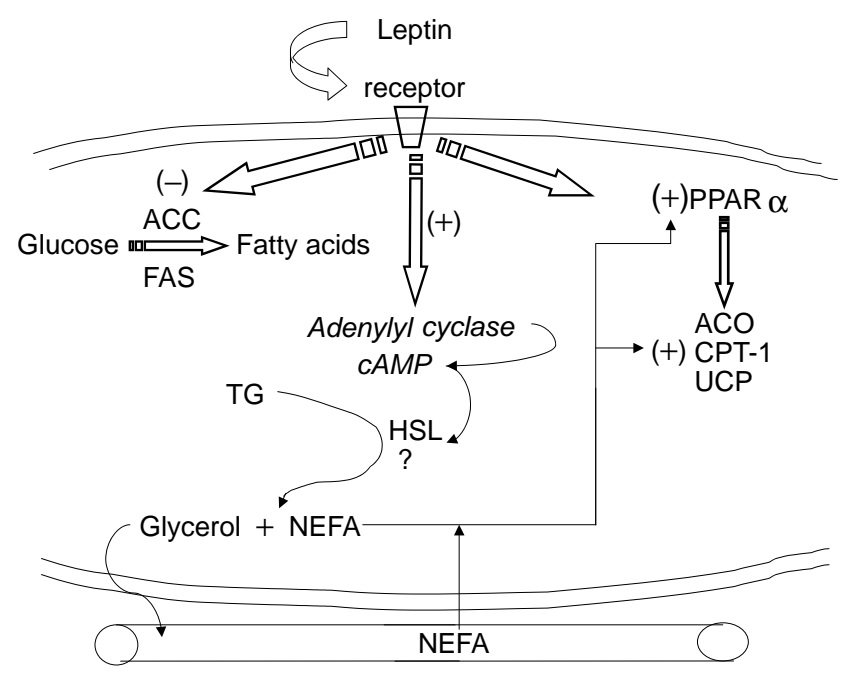

Fig. 3. Model of regulation of lipid metabolism in peripheral tissues by leptin. ACC, acetyl-CoA carboxylase; FAS, fatty acid synthase; $\mathrm{PPAR} \alpha$, peroxisome proliferator activated receptor alpha; TG, triacylglycerols; HSL, hormone-sensitive lipase; ACO, acyl-CoA oxidase; CPT-1, carnitine palmitoyl transferase-1; UCP, uncoupling proteins; NEFA, non-esterified fatty acids; (+), stimulate; $(-)$, inhibit. injections of leptin caused a sustained stimulation of lipid utilization that was reflected in reduced plasma NEFA and triacylglycerol concentrations, and in lower respiratory quotients relative to controls. Furthermore, Reidy \& Weber (2002) determined in rabbits that a single intravenous leptin bolus stimulated lipolysis (increased serum NEFA concentrations) and enhanced triacylglycerol-fatty acid cycling as a means of energy expenditure.

\section{Leptin regulation of lipid accumulation: beyond the adipocyte}

Multiple metabolic complications arise when the lipid content of non-adipocytes rises above tightly controlled normal levels (for a detailed review, see Unger, 2002). Thus, it is of considerable interest that the regulation of lipid metabolism by leptin extends beyond the adipocyte. Leptin deficiency or leptin resistance results in an over-accumulation of triacylglycerol in non-adipocytes, such as pancreatic islet cells, whereas leptin administration or improvements in sensitivity normalize triacylglycerol homeostasis. Early in the development of diet-induced obesity, circulating leptin concentrations rise. Previous work has shown that with an intact leptin-leptin receptor coupling, non-adipocytes maintain normal concentrations of triacylglycerol reserves, even when fed as much as $60 \%$ dietary fat (Zhou et al. 1998); however, in the absence of an intact leptin-leptin receptor axis, excessive accumulation of lipid occurs in islets on as little as $6 \%$ dietary fat. These findings and observations are the foundation on which Unger et al. (1999) proposed that confining intracellular lipid stores to appropriate and nondetrimental concentrations is a major function of leptin in non-adipocytes.

The Zucker diabetic fatty (ZDF) rat has been of considerable interest as a model to study this biological role for leptin. These rats markedly over-accumulate lipid in pancreatic islets, in part because they have tremendous capability for esterification of fatty acids (Lee et al. 1997), and for de novo fatty acid synthesis (Zhou et al. 1998). Chronic hyperleptinaemia in normal controls down regulates lipogenic enzymes and suppresses lipid accumulation from labelled glucose, but has no effect in ZDF rats. Furthermore, islets from normal rats respond similarly to recombinant leptin, in vitro, whereas islets from the receptor-deficient ZDF rats are largely unresponsive (Zhou et al. 1998). Transgenic over-expression of leptin receptors (confined to the liver) of the ZDF rat sensitizes the liver to the anti-steatotic effects of leptin, and further substantiates that this is a direct effect of leptin, rather than a centrally mediated action (Lee et al. 2001).

The mechanism for this critical role of leptin is such that there is a coordinated shift in metabolism from storage to oxidation of fatty acids. Generally, this transition from storage to oxidation involves an enhancement of systems that transport and oxidize fatty acids, and a repression of lipogenic systems similar to what is seen in adipocytes (Fig. 3). However, the principal mechanism differs by tissue, and seems to reflect whether pre-existing oxidative machinery within a given cell type is capable of handling the increased oxidation of lipid brought about by leptin (Lee et al. 2001). 
Skeletal muscle constitutes the major proportion of whole body mass, and is an important determinant of metabolic rate and energy metabolism (Zurlo et al. 1990). There is an intriguing relationship between leptin and lipid metabolism emerging in skeletal muscle that is, overall, quite consistent with the concept that this hormone regulates lipid storage in non-adipocytes and also stimulates skeletal muscle thermogenesis. Early work indicated that leptin acts on skeletal muscle to attenuate the pro-lipogenic actions of insulin (Muoio et al. 1997), and to stimulate fatty acid oxidation while diminishing triacylglycerol accumulation (Muoio et al. 1997, 1999; Steinberg et al. 2002c). Subsequent work has established that with chronic administration of leptin ( 2 weeks), there is a sustained enhancement of fatty acid oxidation and triacylglycerol hydrolysis in rat muscle that is apparent in both the resting and contracting states (Steinberg et al. 2002a). Additional work from this group (Steinberg et al. 2002b) now indicates that chronic leptin administration also diminishes fatty acid transport capacity by reducing the abundance of both the fatty acid translocase and fatty acid-binding protein in plasma membrane fractions of red and white muscles. The activity of the 5'-AMP-activated protein kinase seems to be a critical component by which leptin stimulates fatty acid oxidation in skeletal muscle. Recent work (Minokoshi et al. 2002) has established quite clearly that leptin activates this kinase in skeletal muscle, which monitors intracellular fuel status, and promotes fatty acid oxidation by inhibiting lipogenic activity at the level of acetyl-CoA carboxylase. Although the long-term regulation of this enzyme by leptin may be mediated through a central mechanism, the acute regulation is a direct effect on the skeletal muscle. It is also of interest that this particular mechanism for leptin may be specific to skeletal muscle. Others (Atkinson et al. 2002) determined that whereas leptin also stimulates fatty acid oxidation in cardiac muscle, the effect is achieved independent of activation of the 5'-AMP-activated protein kinase.

The regulation of lipid metabolism in skeletal muscle is conceivably quite important in the development of insulin resistance. Steinberg et al. (2002c), using human skeletal muscle preparations, determined that leptin stimulates fatty acid oxidation in lean subjects, but found preparations from obese individuals to be quite resistant to leptin. Likewise, fatty acid uptake and esterification was greater in the obese subjects, despite higher circulating concentrations of leptin. Though it is inappropriate to extend these findings directly to the in vivo situation, these data suggest that leptin resistance is a factor in the over-accumulation of triacylglycerol in muscle that is associated with insulin resistance and obesity. It is also significant as regards the regulation of lipid in skeletal muscle that Dulloo et al. (2002) have shown that leptin stimulates skeletal muscle thermogenesis in ex vivo preparations from lean mice, and that this response is diminished by diet-induced obesity in the fed state.

As with other peripheral tissues, the leptin receptor has been identified in hepatocytes, and the regulation of lipid metabolism in the liver has received considerable attention. The ob/ob mouse, which lacks functional leptin protein, is characterized by global defects in hepatic lipid metabolism including the regulation of fatty acid synthesis, fatty acid oxidation, cholesterol and bile salt synthesis and transport.
In an elegant experiment using the $o b / o b$ mouse as the model, Liang \& Tall (2001) used suppression subtractive hybridization and cDNA microarray technology to identify genes responding to exogenous leptin ( $v$. pair-fed controls). Consistent with the concept of leptin as a regulator of lipid metabolism in peripheral tissues, and with the essentiality of PPAR $\alpha$ as a mediator of enhanced lipid oxidation in liver (Lee et al. 2002), these researchers identified linkages among PPAR $\alpha$ and genes related to pathways for $\beta$ - and $\omega$ oxidation of fatty acids. Furthermore, a reduction in lipogenic capacity was indicated by reductions in the mRNA of lipogenic genes, such as fatty acid synthase and sterol regulatory element-binding protein (SREBP)-1, which were probably achieved with a reduction in serum insulin.

Over-accumulation of lipid in the liver of $o b / o b$ mice accompanies the leptin deficiency and insulin resistance common to this mouse, and Yahagi et al. (2002) have just reported that the fatty liver condition is attenuated in SREBP-1 knockout mice that were generated on an $o b / o b$ background. It is also of interest to note that leptin deficiency contributes to the fatty liver condition that results from conditions of lipoatrophy (for a detailed review, see Unger, 2002). Exogenous leptin results in marked improvements in lipid homeostasis in the lipoatrophic A-ZIPF-1 mouse, and in the aP2-n SREBP-1 model (Colombo et al. 2002). Thus, the direct or indirect control of SREBP-1 by leptin is critical to the prevention of the fatty liver syndrome that develops with the insulin resistance common to obesity or lipoatrophy. The alterations in gene expression achieved with leptin administration are consistent with an overall suppression of lipogenesis and an enhancement of lipid oxidation, and reflect a metabolic substrate change from carbohydrate to lipid utilization.

\section{Conclusion}

Leptin plays a pivotal role in energy balance and nutrient sensing; its expression and function are regulated by energy intake as well as specific dietary fatty acids. Additionally, there is growing evidence that leptin plays an important role in the regulation of lipid metabolism, and specifically the regulation of lipid storage in adipocytes as well as other tissues including skeletal muscle and the pancreas. Finally, leptin is implicated in nutritional programming that may predispose individuals to adult onset obesity and related metabolic disorders such as diabetes. Additional work is needed to enhance our understanding of the role of specific dietary components in the regulation of leptin expression, function and leptin resistance, as well as the interaction between diet and nutrient intake and the genetic background and physiological and pathophysiological state of the organism being studied.

\section{References}

Ahima RS \& Flier JS (2000) Leptin. Annual Review of Physiology 62, 413-437.

Ahima RS, Prabakaran D, Mantzoros C, Qu D, Lowell BB, Maratosflier E \& Flier JS (1996) Role of leptin in the neuroendocrine response to fasting. Nature 382, 250-252. 
Ahima RS, Saper CB, Flier JS \& Elmquist JK (2000) Leptin regulation of neuroendocrine systems. Frontiers in Neuroendocrinology 21, 263-307.

Ahren B \& Havel PJ (1999) Leptin inhibits insulin secretion induced by cellular cAMP in a pancreatic B cell line (INS-1 cells). American Journal of Physiology 277, 59-66.

Ahren B, Mansson S, Gingerich R \& Havel PJ (1997) Regulation of plasma leptin in mice: Influence of age, high-fat diet, and fasting. American Journal of Physiology 273, R113-R120.

Arch JRS, Stock MJ \& Trayhurn P (1998) Leptin resistance in obese humans: does it exist and what does it mean? International Journal of Obesity 22, 1159-1163.

Atkinson LL, Fischer MA \& Lopaschuk GD (2002) Leptin activates cardiac fatty acid oxidation independent of changes in the AMP-activated protein kinase-acetyl-CoA carboxylase-malonyl-CoA axis. Journal of Biological Chemistry 277, 29424-29430.

Bai Y, Zhang S, Kim K, Lee J \& Kim K (1996) Obese gene expression alters the ability of 30A5 preadipocytes to respond to lipogenic hormones. Journal of Biological Chemistry 271, 13939-13942.

Banks AS, Davis SM, Bates SH \& Myers MG (2000) Activation of downstream signals by the long form of the leptin receptor. Journal of Biological Chemistry 275, 14563-14572.

Banks WA, Kastin AJ, Huang W, Jaspan JB \& Maness LM (1996) Leptin enters the brain by a saturable system independent of insulin. Peptides 17, 305-331.

Barb CR, Hausman GJ \& Houseknecht KL (2001) Biology of leptin in the pig. Domestic Animal Endocrinology 21, 297-317.

Barker DJP (1995) The fetal and infant origins of disease. European Journal of Clinical Investigation 25, 457-463.

Barsh GS, Farooqi IS \& O'Rahilly SO (2000) Genetics of bodyweight regulation. Nature 404, 644-651.

Bartolome B \& Couce ME (2001) Leptin access into the brain. A saturated transport mechanism in obesity. Physiology and Behavior 74, 717-720.

Bjorbaek C, Bucholz RM, Davis SM, Bates SH, Pierroz DD, Gu H, Neel BG, Myers MG \& Flier JS (2001) Divergent roles of SHP-2 in ERK activation by leptin receptors. Journal of Biological Chemistry 276, 4747-4755.

Bjorbaek C, El-Haschimi K, Frantz JD \& Flier JS (1999) The role of SOCS-3 in leptin signaling and leptin resistance. Journal of Biological Chemistry 274, 30059-30065.

Bjorbaek C, Elmquist JK, Michl P, Ahima RS, van Bueren A, McCall AL \& Flier JS (1998) Expression of leptin receptor isoforms in rat brain microvessels. Endocrinology 139, 3485-3489.

Bjorbaek C, Lavery HJ, Bates SH, Olson RK, Davis SM, Flier JS \& Myers MG (2000) SOCS3 mediates feedback inhibition of the leptin receptor via $\mathrm{TYR}^{985}$. Journal of Biological Chemistry 275, 40649-40657.

Boado RJ, Golden PL, Levin N \& Pardridge WM (1998) Up-regulation of blood-brain barrier short-form leptin receptor gene products in rats fed a high fat diet. Journal of Neurochemistry 71, 1761-1764.

Burguera B \& Couce ME (2001) Leptin access into the brain. A saturated transport mechanism in obesity. Physiology and Behavior 74, 717-720.

Campfield LA, Smith FJ, Guisez Y, Devos R \& Burn P (1995) Recombinant mouse OB protein: Evidence for a peripheral signal linking adiposity and central neural networks. Science 269, 546-549.

Caro JF, Sinha MK, Kolaczynski JW, Zhang PL \& Considine RV (1996) Leptin - the tale of an obesity gene. Diabetes 45 , 1455-1462.

Cetin I, Morpurgo PS, Radaelli T, Taricco E, Cortelazzi D, Bellotti M, Pardi G \& Beck-Peccoz P (2000) Fetal plasma leptin con- centrations: relationship with different fetal growth patterns from 19 weeks up to term. Pediatric Research 48, 646-651.

Cha MC \& Jones (1998) Dietary fat type and energy restriction interactively influence plasma leptin concentration in rats. Journal of Lipid Research 39, 1655-1660.

Chen G, Koyama K, Yuan X, Lee Y, Zhou Y-T, O'Doherty R, Newgard CB \& Unger RH (1996) Disappearance of body fat in normal rats induced by adenovirus-mediated leptin gene therapy. Proceedings of the National Academy of Sciences USA 93, 14795-14799.

Chen Y \& Heiman ML (2000) Chronic leptin administration promotes lipid utilization until fat mass is greatly reduced and preserves lean mass of normal female rats. Regulatory Peptides $\mathbf{9 2}$, 113-119.

Chen Y \& Heiman ML (2001) Increased weight gain after ovariectomy is not a consequence of leptin resistance. American Journal of Physiology 280, E315-E322.

Colombo C, Cutson JJ, Yamauchi T, Vinson C, Kadowaki T \& Gavrilova O (2002) Transplantation of adipose tissue lacking leptin is unable to reverse the metabolic abnormalities associated with lipoatrophy. Diabetes 51, 2727-2733.

Considine RV, Cooksey RC, Willims LB, Fawcett RL, Zhang PL, Ambrosius WT, Whitfield RM, Jones R, Inman M, Huse J \& McClain DA (2000) Hexosamines regulate leptin production in human subcutaneous adipocytes. Journal of Clinical Endocrinology and Metabolism 85, 3551-3556.

Doris RA, Kilgour E, Houslay MD \& Vernon RG (1998) Regulation of the GTP-binding protein-based antilipolytic system of sheep adipocytes by growth hormone. Journal of Endocrinology 58, 295-303.

Dulloo AG, Stock MJ, Solinas G, Boss O, Montani J-P \& Seydoux J (2002) Leptin directly stimulates thermogenesis in skeletal muscle. FEBS Letters 515, 109-113.

Ekert JE, Gatford KL, Luxford BG, Campbell RG \& Owens PC (2000) Leptin expression in offspring is programmed by nutrition in pregnancy. Journal of Endocrinology 165, R1-R6.

El-Haschimi K, Pierroz DD, Hileman SM, Bjorbaek C \& Flier JS (2000) Two defects contribute to hypothalamic leptin resistance in mice with diet-induced obesity. Journal of Clinical Investigation 105, 1827-1832.

Elias CF, See C, Kelly J, Aschkenasi C, Ahima RS, Couceyro PR, Kuha MJ, Saper CB \& Elmquist JK (1999) Leptin differentially regulates NPY and POMC neurons projecting to the lateral hypothalamic area. Neuron 23, 775-786.

Elmquist JK, Elias CF \& Saper CB (1999) From lesions to leptin: hypothalamic control of food intake and body weight. Neuron 22, 221-232.

Emanuelli B, Peraldi P, Filloux C, Chavey C, Freidinger K, Hilton DJ, Hotamisligil GS \& Van Obberghen E (2001) SOCS-3 inhibits insulin signaling and is up-regulated in response to tumor necrosis factor- $\alpha$ in the adipose tissue of obese mice. Journal of Biological Chemistry 276, 47944-47949.

Faggioni R, Geingold KR \& Grunfeld C (2001) Leptin regulation of the immune response and the immunodeficiency of malnutrition. FASEB Journal 15, 2565-2571.

Fan W, Boston BA, Kesterson RA, Hruby VJ \& Cone RD (1997) Role of melanocortinergic neurons in feeding and the agouti obesity syndrome. Nature $\mathbf{3 8 5}, 165-168$.

Fantuzzi G \& Faggioni R (2000) Leptin in the regulation of immunity, inflammation, and hematopoiesis. Journal of Leukocyte Biology 68, 437-446.

Farooqi IS, Yeo GS, Keogh JM, Aminian S, Jebb SA, Butler G, Cheetham T \& O'Rahilly S (2000) Dominant and recessive inheritance of morbid obesity associated with melanocortin 4 receptor deficiency. Journal of Clinical Investigation 106, 271-279.

Finn PD, Cunningham MJ, Pau KY, Speis HG, Clifton DK \& 
Steiner RA (1998) The stimulatory effect of leptin on the neuroendocrine reproductive axis of the monkey. Endocrinology 139, 4652-4662.

Flier JS (1998) Clinical review 94: What's in a name? In search of leptin's physiologic role. Journal of Clinical Endocrinology and Metabolism 83, 1407-1413.

Friedman JM \& Halaas JL (1998) Leptin and the regulation of body weight in mammals. Nature 395, 763-770.

Frühbeck G, Aguado M, Gomez-Ambrosi J \& Martinez JA (1998) Lipolytic effect of in vivo leptin administration on adipocytes of lean and ob/ob mice, but not $\mathrm{db} / \mathrm{db}$ mice. Biochemical and Biophysical Research Communications 250, 99-102.

Frühbeck G, Aguado M \& Martinez JA (1997) In vitro lipolytic effect of leptin on mouse adipocytes: Evidence for a possible autocrine/paracrine role of leptin. Biochemical and Biophysical Research Communications 240, 590-594.

Frühbeck G, Gomez-Ambrosi J \& Salvador J (2001) Leptininduced lipolysis opposes the tonic inhibition of endogenous adenosine in white adipocytes. FASEB Journal 15, 333-340.

Gabriely I, Ma XH, Yang XM, Rossetti L \& Barzilai N (2002) Leptin resistance during aging is independent of fat mass. Diabetes 51, 1016-1021.

Gibson RA, McMurchie EJ, Charnock JS \& Kneebone GM (1984) Homeostatic control of membrane fatty acid composition in the rat after dietary lipid treatment. Lipids 19, 942-951.

Giraudo SQ, Kotz CM, Grace MK, Levine AS \& Billington CJ (1994) Rat hypothalamic NPY mRNA and brown fat uncoupling protein mRNA after high-carbohydrate or high fat diets. American Journal of Physiology 266, R1578-R1583.

Guan XM, Yu H, Trumbauer M, Frazier E, Van der Ploeg LH \& Chen H (1998) Induction of neuropeptide Y expression in dorsomedial hypothalamus of diet-induced obese mice. Neuroreport 9, 3415-3419.

Halaas JL, Gajiwala KS, Maffei M, Cohen SL, Chait BT, Rabinowitz D, Lallone RL, Burley SK \& Friedman JM (1995) Weight-reducing effects of the plasma protein encoded by the obese gene. Science 269, 543-546.

Higa M, Kakuma T, Pan W, Wang ZW, Babcock E, McCorkler K, Lee Y \& Unger R (2000) Slow recovery of body fat lost during adenovirus-induced hyperleptinemia. Biochemical and Biophysical Research Communications 279, 786-791.

Hileman SM, Pierroz DD, Masuzaki H, Bjorbaek C, El-Haschimi K, Banks WA \& Flier JS (2002) Characterization of short isoforms of the leptin receptor in rat cerebral microvessels and of brain uptake of leptin in mouse models of obesity. Endocrinology 143, 775-783.

Houseknecht KL \& Bauman DE (1997) Regulation of lipolysis by somatotropin: functional alteration of adrenergic and adenosine signaling in bovine adipose tissue. Journal of Endocrinology 152, 465-475.

Houseknecht KL, Mantzoros CS, Kulaiawat R, Hadro E, Flier JS \& Kahn BB (1996) Evidence for leptin binding to proteins in serum of rodents and humans: Modulation with obesity. Diabetes 45, 1638-1643.

Houseknecht KL \& Portocarrero CP (1998) Leptin and its receptors: Regulators of whole-body energy homeostasis. Domestic Animal Endocrinology 15, 457-475.

Houseknecht KL, Vanden Heuvel JP, Moya-Camarena SY, Portocarrero CP, Peck LW, Nickel KP \& Belury MA (1998) Dietary conjugated linoleic acid normalizes impaired glucose tolerance in the Zucker Diabetic Fatty fa/fa rat. Biochemical and Biophysical Research Communications 244, 678-682.

Huszar D, Lynch CA, Fairchild-Huntress V, Dunmore JH, Fang Q, Berkemeier LR, Gu W, Kesterson RA, Bosoton BA, Cone RD, Smith FJ, Campfield LA, Burn P \& Lee F (1997) Targeted disruption of the melanocortin-4 receptor results in obesity in mice. Cell 88, 131-141.
Kang KW \& Pariza MW (2001) Trans-10, cis-12-conjugated linoleic acid reduces leptin secretion from 3T3-:1 adipocytes. Biochemical and Biophysical Research Communications 287, 377-382.

Kopelman PG (2000) Obesity as a medical problem. Nature 404, 635-643.

Krebs DL \& Hilton DJ (2000) SOCS: physiological suppressors of cytokine signaling. Journal of Cell Science 113, 2813-2819.

Laimer M, Ebenbichler CF, Kaser S, Sandhofer A, Weiss H, Nehoda H, Aigner F \& Patsch JR (2002) Weight loss increases soluble leptin receptor levels and the soluble receptor bound fraction of leptin. Obesity Research 10, 597-601.

Lee Y, Hirose H, Zhou YT, Esser V, McGarry JD \& Unger RH (1997) Increased lipogenic capacity of the islets of obese rats: a role in the pathogenesis of NIDDM. Diabetes 46, 408-413.

Lee Y, Wang MY, Kakuma T, Wang ZW, Babcock E, McCorkle K, Higa M, Zhou YT \& Unger RH (2001) Liporegulation in dietinduced obesity. The antisteatotic role of hyperleptinemia. Journal of Biological Chemistry 276, 5629-5635.

Lee Y, Yu X, Gonzales F, Mangelsdorf DJ, Wang MY, Richardson C, Witters LA \& Unger RH (2002) PPAR alpha is necessary for the lipopenic action of hyperleptinemia on white adipose and liver tissue. Proceedings of the National Academy of Sciences USA 99, 11848-11853.

Legradi G, Emberson CH, Ahima RS, Flier JS \& Lechan RM (1997) Leptin prevents fasting-induced suppression of prothyrotropin-releasing hormone messenger ribonucleic acid in neurons of the hypothalamic paraventricular nucleus. Endocrinology 138, 2569-2576.

Li H, Matheny M, Nicolson M, Tumer N \& Scarpace PJ (1997) Leptin gene expression increases with age independent of increasing adiposity in rats. Diabetes 46, 2035-2039.

Liang CP \& Tall AR (2001) Transcriptional profiling reveals global defects in energy metabolism, lipoprotein, and bile acid synthesis and transport with reversal by leptin treatment in ob/ob mouse liver. Journal of Biological Chemistry 276, 49066-49076.

Lin J, Barb CR, Kraeling RR \& Rampacek G (2001a) Developmental changes in the long form leptin receptor and related neuropeptide gene expression in the pig brain. Biology of Reproduction 64, 1614-1618.

Lin L, Martin R, Schaffhauser AO \& York DA (2001b) Acute changes in the response to peripheral leptin with alteration in the diet composition. American Journal of Physiology 280, R504-R509.

Lin S, Storlein LH \& Huang X (2000) Leptin receptor, NPY, POMC mRNA expression in the diet-induced obese mouse brain. Brian Research 875, 89-95.

Lin X, Chavez MR, Bruch RC, Kilroy GE, Simmons LA, Lin L, Braymer HD, Bray GA \& York DA (1998) The effects of a high fat diet on leptin mRNA, serum leptin and the response to leptin are not altered in a rat strain susceptible to high fat diet-induced obesity. Journal of Nutrition 128, 1606-1613.

Löllmann B, Gruninger S, Stricker-Krongrad A \& Chiesi M (1997) Detection and quantification of the leptin receptor splice variants Ob-Ra, b, and $\mathrm{e}$ in different mouse tissues. Biochemical and Biophysical Research Communications 238, 648-652.

Lord GM, Matarese G, Howard JK, Baker RJ, Bloom SR \& Lechler RI (1998) Leptin modulates the T-cell immune response and reverses starvation-induced immunosuppression. Nature 394, 897-901.

Lucas A (1994) Role of nutritional programming in determining adult morbidity. Archives of Disease in Childhood 71, 288-290.

McClain DA, Alexander T, Cooksey RC \& Considine RV (2000) Hexosamines stimulate leptin production in transgenic mice. Endocrinology 141, 1999-2002. 
Madej T, Boguski MS \& Bryant SH (1995) Threading analysis suggests that the obese gene product may be a helical cytokine. FEBS Letters 373, 13-18.

Mark AL, Correia MLG, Rahmouni K \& Haynew WG (2002) Selective leptin resistance: a new concept in leptin physiology with cardiovascular implications. Journal of Hypertension $\mathbf{2 0}$, 1245-1250.

Marshall S, Garvey WT \& Traxinger RR (1991) New insights into the metabolic regulation of insulin action and insulin resistance: role of glucose and amino acids. FASEB Journal 5, 3031-3036.

Medina EA, Horn WF, Keim NL, Havel PJ, Benito P, Kelley DS, Nelson GJ \& Erickson KL (2000) Conjugated linoleic acid supplementation in humans: Effects on circulating leptin concentrations and appetite. Lipids 35, 783-788.

Minokoshi Y, Kim YB, Peroni OD, Fryer LG, Muller C, Carling D \& Kahn BB (2002) Leptin stimulates fatty-acid oxidation by activating AMP-activated protein kinase. Nature 17, 339-343.

Monteleone P, Fabrazzo M, Tortorella A, Fuschino A \& Maj M (2002) Opposite modifications in circulating leptin and soluble leptin receptor across the eating disorder spectrum. Molecular Psychiatry 7, 641-646.

Mooradian AD, Chehade J, Hurd R \& Haas MJ (2000) Monosaccharide-enriched diets cause hyperleptinemia without hypophagia. Nutrition 16, 439-441.

Moschos S, Chan JL \& Mantzoros CS (2002) Leptin and reproduction: a review. Fertility and Sterility 77, 433-444.

Mueller W, Gregoire FM, Stanhope K, Mobbs CV, Mizuno TM, Warden C, Stern JS \& Havel PJ (1998) Evidence that glucose metabolism regulates leptin secretion from cultured rat adipocytes. Endocrinology 139, 551-558.

Müller G, Ertl J, Gerl M \& Preibisch G (1997) Leptin impairs metabolic actions of insulin in isolated rat adipocytes. Journal of Biological Chemistry 272, 10585-10593.

Muoio DM, Dohm GL, Tapscott EB \& Coleman RA (1999) Leptin opposes insulin's effect on fatty acid partitioning in muscles isolated from obese ob/ob mice. American Journal of Physiology 276, E913-E921.

Muoio DM, Fiedorek FT Jr, Taspscot EB, Coleman RA \& Dohm GL (1997) Leptin directly alters lipid partitioning in skeletal muscle. Diabetes 46, 1360-1363.

Nagatani S, Guthikonda P, Thompson RC, Tsukamura H, Maeda KI \& Foster DL (1998) Evidence for GnRH regulation by leptin: Leptin administration prevents reduced pulsatile LH secretion during fasting. Neuroendocrinology 67, 370-376.

Nicola NA \& Greenhalgh CJ (2000) The suppressors of cytokine signaling (SOCS) proteins. Important feedback inhibitors of cytokine action. Experimental Hematology 28, 1105-1112.

Obici S, Feng ZH, Morgan Y, Stein D, Karkanias G \& Rossetti L (2002a) Central administration of oleic acid inhibits glucose production and food intake. Diabetes 51, 271-275.

Obici S, Wang J, Chowdury R, Feng Z, Siddhanta U, Morgan K \& Rossetti (2002b) Identification of a biochemical link between energy intake and energy expenditure. Journal of Clinical Investigation 109, 1599-1605.

Ogier V, Ziegler O, Mejean L, Nicolas JP \& Stricker-Krongrad A (2002) Obesity is associated with decreasing levels of the circulating soluble leptin receptor in humans. International Journal of Obesity 26, 496-503.

Park Y, Albright KJ, Liu W, Storkson JM, Cook ME \& Pariza MW (1997) Effects of conjugated linoleic acid on body composition in mice. Lipids 32, 853-858.

Park Y, Storkson JM, Albright KJ, Liu W \& Pariza MW (1999) Evidence that the trans-10, cis-12 isomer of conjugated linoleic acid induces body composition changes in mice. Lipids $\mathbf{3 4}$, 235-241.

Pelleymounter MA, Cullen MJ, Baker MB, Heckt R, Winters D, Boone T \& Collins F (1995) Effects of the obese gene product on body weight regulation in ob/ob mice. Science 269, 540-543.
Peyron-Caso E, Taverna M, Guerre-Millo M, Veronese A, Pacher N, Slama G \& Rizkalla SW (2002) Dietary (n-3) polyunsaturated fatty acids up-regulate plasma leptin in insulin-resistant rats. Journal of Nutrition 132, 2235-2240.

Qian H, Azain MJ, Hartzell DL \& Baile CA (1998a) Increased leptin resistance as rats grow to maturity. Society for Experimental Biology and Medicine 219, 160-165.

Qian H, Hartzell DL, Baile CA, Azain MJ, Compton MM \& Hausman GJ (1998b) Brain administration of leptin causes deletion of adipocytes by apoptosis. Endocrinology 139, 791-794.

Raclot T, Groscolas R, Langin D \& Ferre P (1997) Site-specific regulation of gene expression by $n-3$ polyunsaturated fatty acids in rat white adipose tissues. Journal of Lipid Research 38, 1963-1972.

Rahman SM, Want YM, Yotsumoto H, Cha JY, Han SY, Inoue S \& Yanagita T (2001) Effects of conjugated linoleic acid on serum leptin concentration, body-fat accumulation, and betaoxidation for fatty acid in OLETF rats. Nutrition 17, 385-390.

Ramsay TG (1996) Fat cells. Endocrinology and Metabolism Clinics of North America 25, 847-870.

Ramsay TG (2001) Porcine leptin alters insulin inhibition of lipolysis in porcine adipocytes in vitro. Journal of Animal Science 79, 653-657.

Ravelli JP, Stein ZA \& Susser MW (1976) Obesity in young men after famine exposure in utero and early infancy. New England Journal of Medicine 295, 349-353.

Reidy SP \& Weber JM (2002) Accelerated substrate cycling: a new energy-wasting role for leptin in vivo. American Journal of Physiology 282, E312-E317.

Reynolds RM \& Phillips DIW (1998) Long-term consequences of intrauterine growth retardation. Hormone Research 49, 28-31.

Ryder JW, Portocarrero CP, Song XM, Cui L, Yu M, Combatsiaris T, Galuska D, Bauman DE, Barbano DM, Charron MJ, Zierath JR \& Houseknecht KL (2001) Isomer-specific anti-diabetic properties of conjugated linoleic acid (CLA): Improved glucose tolerance, skeletal muscle insulin action and UCP-2 gene expression. Diabetes 50, 1149-1157.

Sanchez-Rodriguez M, Garcia-Sanchez A, Retana-Ugalde R \& Mendoza-Nunez VM (2000) Serum leptin levels and blood pressure in the overweight elderly. Archives of Medical Research 31, 425-428.

Sarmiento U, Benson B, Kaufman S, Ross L, Qi M, Scully S \& DiPalma C (1997) Morphologic and molecular changes induced by recombinant human leptin in the white and brown adipose tissues of C57BL/6 mice. Laboratory Investigation 77, 243-256.

Scarpace PJ, Matheny M, Zhang Y, Shek EW, Prima V, Zolotukhin S \& Tumer N (2002a) Leptin-induced leptin resistance reveals separate roles for the anorexic and thermogenic responses in weight maintenance. Endocrinology 143, 3026-3035.

Scarpace PJ, Matheny M, Zhang Y, Tumer N, Frase CD, Shek EW, Hong B, Prima V \& Zolotukhin S (2002b) Central leptin gene delivery evokes persistent leptin signal transduction in young and aged-obese rats but physiological responses become attenuated over time in aged-obese rats. Neuropharmacology 42, 549-562.

Scarpace PJ, Nicolson M \& Matheny M (1998) UCP1, UCP3 and leptin gene expression: modulation by food restriction and leptin. Journal of Endocrinology 159, 349-357.

Scarpace PJ \& Tumer N (2001) Peripheral and hypothalamic leptin resistance with age-related obesity. Physiology and Behavior 74, 721-727.

Schwartz MW (2001) Brain pathways controlling food intake and body weight. Experimental Biology and Medicine 226, 978-981.

Schwartz MW, Seeley RJ, Woods SC, Weigle DS, Campfield LA, 
Burn P \& Baskin DG (1997) Leptin increases hypothalamic proopiomelanocortin (POMC) mRNA expression in the rostral arcuate nucleus. Diabetes 46, 2119-2123.

Shimabukuro M, Koyama K, Lee Y \& Unger RH (1997) Leptinor troglitazone-induced lipopenia protects islets from interleukin 1 beta cytotoxicity. Journal of Clinical Investigation 100, 1750-1754.

Silverman BL, Rizzo T, Green OC, Cho NH, Winter RJ, Ogata ES, Richards GE \& Metzger BE (1991) Long-term prospective evaluation of offspring of diabetic mothers. Diabetes $\mathbf{4 0}$, 121-125.

Singhal A, Farooqi IS, O'Rahilly S, Cole TJ, Fewtred M \& Lucas A (2002) Early nutrition and leptin concentrations in later life. American Journal of Clinical Nutrition 75, 993-999.

Sinha MK, Opentanova I, Ohannesian JP, Kolacynski JW, Hale L, Becker GW, Bowsher RR, Stephens TW \& Caro JF (1996) Evidence of free and bound leptin in human circulation. Studies in lean and obese subjects and during short-term fasting. Journal of Clinical Investigation 98, 1277-1282.

Slieker LJ, Sloop KW, Surface PL, Kriauciunas A, LaQuier F, Manetta J, Bue-Valleskey J \& Stephens TW (1996) Regulation of expression of ob mRNA and protein by glucocorticoids and cAMP. Journal of Biological Chemistry 271, 5301-5304.

Spurlock ME, Houseknecht KL, Portocarrero CP, Cornelius SG, Willis GM \& Bidwell CA (2000) Regulation of PPAR $\gamma$ but not obese gene expression by dietary fat supplementation. Journal of Nutritional Biochemistry 11, 260-266.

Steinberg GR, Bonen A \& Dyck DJ (2002a) Fatty acid oxidation and triacylglycerol hydrolysis are enhanced after chronic leptin treatment in rats. American Journal of Physiology 282, E593-E600.

Steinberg GR, Dyck DJ, Calles Escandon J, Tandon NN, Luiken JJ, Glatz JF \& Bonen A (2002b) Chronic leptin administration decreases fatty acid uptake and fatty acid transporters in rat skeletal muscle. Journal of Biological Chemistry 277, 8854-8860.

Steinberg GR, Parolin ML, Heigenhauser GJ \& Dyck DJ (2002c) Leptin increases fatty acid oxidation in lean but not obese human skeletal muscle: evidence of peripheral leptin resistance. American Journal of Physiology 283, E187-E192.

Sweeney G (2002) Leptin signaling. Cellular Signaling 14, 655-663.

Takahashi Y \& Ide T (2000) Dietary n-3 fatty acids affect mRNA level of brown adipose tissue uncoupling protein 1, and white adipose tissue leptin and glucose transporter 4 in the rat. British Journal of Nutrition 84, 175-184.

Tartaglia L, Dembski M, Weng X, Deng N, Culpepper J, Deros R, Richards GJ, Camfield LA, Clark FT, Deeds J, Muri C, Sanker S, Moriarty A, Moore KJ, Smutoko JS, Mays GG, Woolf EA, Monroe CA \& Tepper RI (1995) Identification and expression cloning of a leptin receptor. Cell 83, 1263-1271.

Tartaglia LA (1997) The leptin receptor. Journal of Biological Chemistry 272, 6093-6096.

Thomas T \& Burguera B (2002) Is leptin the link between fat and bone mass? Journal of Bone and Mineral Research 17, $1563-1569$.

Tsuboyama-Kasaoka N, Takahashi M, Tanemura K, Kim HJ, Tange T, Okuyama H, Kasai M, Ikemoto S \& Ezaki O (2000) Conjugated linoleic acid supplementation reduces adipose tissue by apoptosis and develops lipodystrophy in mice. Diabetes 49, 1534-1542.

Unger RH (2002) Lipotoxic Diseases. Annual Review of Medicine 53, 319-336.

Unger RH, Zhou YT \& Orci L (1999) Regulation of fatty acid homeostasis in cells: novel role of leptin. Proceedings of the National Academy of Sciences USA 96, 2327-2332.

Van Heek M, Compton DS, France CF, Tedesco RP, Fawzi AB,
Graziano MP, Sybertz EJ, Strader CD \& Davis HR (1997) Dietinduced obese mice develop peripheral, but not central, resistance to leptin. Journal of Clinical Investigation 99, 385-390.

Vickers MH, Breier BH, Cutfield WS, Hofman PL \& Gluckman PD (2000) Fetal origins of hyperphagia, obesity, and hypertension and postnatal amplification by hypercaloric nutrition. American Journal of Physiology 279, E83-E87.

Vickers MH, Ikenasio BA \& Breier BH (2001) IGF-1 treatment reduces hyperphagia, obesity and hypertension in metabolic disorders induced by fetal programming. Endocrinology 142, 3964-3973.

Wang H, Storlien LH \& Huang XF (1999a) Influence of dietary fats on c-Fos-like immunoreactivity in mouse hypothalamus. Brain Research 843, 184-192.

Wang J, Liu R, Hawkins M, Barzilai N \& Rossetti L (1998) A nutrient-sensing pathway regulates leptin gene expression in muscle and fat. Nature 393, 684-688.

Wang J, Liu R, Liu L, Chowdhury R, Barzilai N, Tan J \& Rossetti $\mathrm{L}(1999 b)$ The effects of leptin on Lep expression is tissue-specific and nutritionally regulated. Nature Medicine 5, 895-899.

Wang J, Storlien LH \& Huang XF (2002) Effects of dietary fat types on body fatness, leptin and ARC leptin receptor, NPY and AgRP mRNA expression. American Journal of Physiology 282, E1352-E1359.

Wang JL, Obici S, Morgan K, Barzilai N, Feng ZH \& Rossetti L (2001a) Overfeeding rapidly induces leptin and insulin resistance. Diabetes 50, 2786-2791.

Wang M, Lee Y \& Unger RH (1999c) Novel form of lipolysis induced by leptin. Journal of Biological Chemistry 274, 17541-17544.

Wang ZW, Pan WT, Lee Y, Kakuma T, Zhou YT \& Unger RH (2001b) The role of leptin resistance in the lipid abnormalities of aging. FASEB Journal 15, 108-114.

West DB, Delany JP, Camet PM, Blohm F, Truett AA \& Scimeca J (1998) Effects of conjugated linoleic acid on body fat and energy metabolism in the mouse. American Journal of Physiology 275, R667-R672.

White DW, Kuropatwinski KK, Devos R, Baumann H \& Tartaglia LA (1997) Leptin receptor (OB-R) signaling. Cytoplasmic domain mutational analysis and evidence for receptor homooligomerization. Journal of Biological Chemistry $\mathbf{2 7 2}$, 4065-4071.

Widdowson PS, Upton R, Buckingham R, Arch J \& Williams G (1997) Inhibition of food response to intracerebroventricular injection of leptin is attenuated in rats with diet-induced obesity. Diabetes 46, 1782-1785.

Yahagi N, Shimano H, Hasty AH, Matsuzaka T, Ide T, Yoshikawa T, Amemiya-Kudo M, Tomita S, Okazaki H, Taura Y, Lizuka Y, Ohashi K, Osuga J, Harada K, Gotoda T, Nagai R, Ishibashi S \& Yamada N (2002) Absence of sterol regulatory element-binding protein-1 (SREBP-1) ameliorates fatty livers but not obesity or insulin resistance in $\operatorname{Lep}(\mathrm{ob}) / \mathrm{Lep}(\mathrm{ob})$ mice. Journal of Biological Chemistry 277, 19353-19357.

Yamasaki M, Mansho K, Ogino Y, Kasai M, Tachibana H \& Yamada K (2000) Acute reduction of serum leptin level by dietary conjugated linoleic acid in Sprague-Dawley rats. Journal of Nutritional Biochemistry 11, 467-471.

Yu WH, Kimura M, Walczewska A, Karanth S \& McCann SM (1997) Role of leptin in hypothalamic-pituitary function. Proceedings of the National Academy of Sciences USA 94, 1023-1028.

Zhang PL, Klenk ES, Lazzaro MA, Williams LB \& Considine RV (2002) Hexosamines regulate leptin production in 3T3-L1 adipocytes through transcriptional mechanisms. Endocrinology 143, 99-106.

Zhang Y, Proenca R, Maffei M, Barone M, Leopold L \& Friedman JM (1994) Positional cloning of the mouse obese gene and its human homologue. Nature 372, 425-432. 
Zhao A, Bornfeldt KE \& Beavo JA (1998) Leptin inhibits insulin secretion by activation of phosphodiesterase $3 \mathrm{~B}$. Journal of Clinical Investigation 102, 869-873.

Zhao A, Shinohara M \& Huang D (2000) Leptin induces insulinlike signaling that antagonizes cAMP elevation by glucagon in hepatocytes. Journal of Biological Chemistry 275, 11348-11354.

Zhou TY, Wang ZW, Higa M, Newgard CB \& Unger RH (1999) Reversing adipocyte differentiation: implications for treatment of obesity. Proceedings of the National Academy of Sciences USA 96, 2391-2395.
Zhou YT, Shimabukuro M, Lee Y, Koyama K, Higa M, Ferguson T \& Unger RH (1998) Enhanced de novo lipogenesis in leptinunresponsive pancreatic islets of prediabetic Zucker diabetic fatty rats: role in the pathogenesis of lipotoxic diabetes. Diabetes 47, 1904-1908.

Zurlo F, Larson K, Bogardus C \& Ravussin E (1990) Skeletal muscle metabolism is a major determinant of resting energy expenditure. Journal of Clinical Investigation 86, 1423-1427. 